\title{
Sejarah Masuknya Islam dan Pendidikan Islam Masa Kerajaan Banten Periode 1552-1935
}

\author{
Muslimah \\ IAIN Palangka Raya \\ muslimah.abdulazis@iain-palangkaraya.ac.id
}

\begin{abstract}
The coming of islamic scholars as Islamic spreader in Banten must deal with the condition of the people who had embraced Hinduism. The people were already familiar with the superstitions of heresy and khurafat. The cause of this condition were stupidity, clumsiness and Dutch colonialism. This literature review will ease the observers of history and Islamic education, because this literature review discusses specifically and systematically about the history of the entry of Islam and Islamic education in the Sultanate of Banten in the period of 1552-1935 years. The findings of this study explain that the entry of Islam in the Sultanate of Banten was done peacefully by Sharif Hidayatullah (Sunan Gunung Jati) together with his son, Maulana Hasanudin, who then became the first sultan of Sultanate of Banten, continued by Maulana Yusuf and the next sultans; What Islamic scholars did in the Sultanate of Banten such as spreading the teachings of Islam as well as balancing life and religion, eradicating stupidity and encouraging jihad against the invaders; At first, Islamic educational institutions in Banten were conducted in homes and mosques individually and then got developed into madrasah.
\end{abstract}

Keywords: Islamic History, Education, Banten.

\section{A. Pendahuluan}

Membahas mengenai islamisasi Banten atau masuknya Islam di Banten, menurut tradisi sebagaimana disebutkan dalam berbagai babad, diceritakan bahwa setelah dikuasainya Pelabuhan Sunda-Pakwan, ulama yang bergelar Sunan Gunung Jati dari Cirebon, meminta anaknya Maulana Hasanuddin untuk bertahan dan mengembangkan Islam dan memperkuat kedudukan Banten. Selain itu, juga berhasil mengislamkan bagian barat pantai pelabuhan Banten, serta pelabuhan Sunda Kepala. ${ }^{1}$

\section{B. Kajian Pustaka}

1 Bambang Budi Utomo et al., Atlas sejarah Indonesia: masa Islam (Jakarta]; Kharisma Ilmu: Direktorat Geografi Sejarah, Direktorat Jenderal Sejarah dan Purbakala, Kementerian Kebudayaan dan Pariwisata ;, 2012), 82. 
Semenjak berdirinya Kesultanan Banten, Para sultan yang memimpin tidak hanya sebagai penguasa pihak pemerintah, tetapi juga sebagai penyiar agama Islam, ada yang berperan sebagai dai, imam shalat, guru, dan penggerak pendidikan Islam. Terlebih lagi dengan para ulama, yang tidak hanya berperan sebagai penyampai ajaran Islam, tetapi harus berhadapan dengan kondisi masyarakat yang berada dalam jajahan Bangsa Belanda, juga berhadapan dengan kehidupan masyarakat yang kental dengan tahayul, bid'ah, dan khurafat.

Para ulama Banten menyadari betul jika untuk merubah pola fikir dan kehidupan masyarakat Banten harus dilakukan dengan penguasaan ilmu termasuk ilmu agama Islam, tetapi masyarakat Banten tidak dapat memenuhi harapannya karena keterbatasan lembaga pendidikan dan harus berhadapan dengan aturan penjajah Benlanda yang pilih kasih dalam memberi kesempetan anak pribumi untuk bersekolah. Menyebabkan para ulama berupaya untuk memenuhinya sendiri, dimulai dengan mengajarkan agama Islam secara individual di rumah dan masjid terdekat, berkembang sampai mendirikan lembaga pendidikan yang sesuai dengan kehendak dan kebutuhan masyarakat Banten dan sekitar Banten.

Bagaimanakah sejarah masuknya Islam di Banten yang tengah menjadi rebutan penjajah Belanda dan kondisi masyarakatnya yang masih jumud; bagaimana dengan peran ulama yang berupaya menyebarkan Islam di Banten; dan lembaga pendidikan Islam apa saja yang didirikan dan berkembang sebagai upaya pemenuhan terhadap kebutuhan masyarakat Banten akan pendidikan. Untuk mengetahuinya, akan dibahas dalam tulisan ini dengan mengambil fakta sejarah melalui refrensi dari hasil penelitian dan penelusuran tulisan resmi yang sudah dibukukan.

Oleh karena penulis belum menemukan tulisan yang secara khusus dan sistematis membahas tentang masuknya Islam dan keberadaan lembaga pendidikan Islam dalam satu bahasan, dalam arti masih terpisah-pisah secara sendiri-sendiri. Sehingga penulis membahasnya dalam artikel jurnal ini dengan judul "sejarah masuknya Islam dan pendidikan Islam pada masa kerajaan Banten”. Penulis membatasinya pada periode tahun 1552 sampai tahun 1930. Semoga dapat membantu bagi yang berkepentingan dengan tulisan ini untuk 
mengetahui sejarah masuknya Islam dan relevansinya dengan pendirian lembaga pendidikan Islam di Banten. Pembahasan masuknya Islam, penulis khususkan mendalaminya pada awal sejarah masuknya Islam di Banten.

\section{Metode Penelitian}

Penelitian ini merupakan library research (penelitian pustaka) yang menggunakan metode Deskriptif Analitis dengan menggunakan referensi-referensi yang berhubungan dengan judul tersebut yang kemudian dianalisis.

\section{Pembahasan}

\section{Sejarah Islam Di Kerajaan Banten}

Banten memang memiliki daya tarik tersendiri, selain merupakan daerah yang sangat strategis, karena terletak di pesisir Selat Sunda, juga merupakan pintu gerbang yang menghubungkan Sumatra dan Jawa. Posisi ini mendukung terhadap mudahnya penyebaran Islam dan menjadikan pelabuhan Banten semakin ramai.2

Strategisnya Banten sebagai kota terbuka, berhasil dimanfaatkan oleh Sunan Gunung Jati yang memberdayakan putranya Pangeran Hasanuddin untuk membangun kesultanan Banten dan diangkat sebagai raja atau sultan yang pertama. Semua catatan sejarah menuliskan jika Sultan Hasanuddin memerintah dengan baik, di bawah kepemimpinannya Banten menjadi kuat, islamisasi dianggap, dibuktikan dengan semakin banyaknya yang memeluk agama Islam, dan semakin meluasnya wilayah Islam di Banten meliputi: Serang, Pandeglang, Lebak, dan Tangerang.

Sultan Hasanuddin memerintah Banten selama kurang lebih 18 tahun (1552-1570). Ia telah memberikan andil besar dalam meletakkan pondasi Islam di nusantara. Selain dengan mendirikan masjid dan pesantren tradisonal, juga mengirim ulama ke berbagai daerah yang telah dikuasainya sebagai upaya menyebarluaskan Islam untuk pembangunan mental spiritual Banten. Keberhasilannya membangun istana yang selanjutnya dinamakan Surosowan dan menjadi ibu kota Kerajan Banten sebagai pusat pemerintahan Kesultanan Islam,

2 Uka Tjandrasasmita, Arkeologi Islam Nusantara (Kepustakaan Populer Gramedia, 2009), 10. 
semakin memperkuat Banten dengan Islamnya, karena menjadi pusat pertemuan dan pembelajaran agama Islam.

Selanjutnya Maulana Yusuf, putra yang menggantikan Maulana Hasanuddin menaiki tahta kerajaan tahun 1570, juga berhasil memperluas wilayah penyebaran Islam ke daerah Banten bagian selatan, bahkan berhasil menduduki ibu kota Kerajaan Pajajaran-Sunda di Pakwan pada tahun 1580. Setelah Maulana Yusuf wafat, tahta Banten dilanjutkan oleh putranya yang bernama Maulana Muhammad. Maulana Muhammad gugur pada saat memperluas wilayah Islam ke Palembang, pada saat itu ia meninggalkan seorang Putra Mahkota yang baru berusia sembilan tahun bernama Sultan Abdul Mufakhir Mahmud. Selanjutnya, pemerintahan Banten dipegang oleh Dewan Perwakilan Banten yang terdiri atas gadhi dan para bangsawan. ${ }^{3}$ Uraian tersebut, menunjukkan bahwa terdapat tiga tokoh utama terhadap awal masuknya Islam di Banten, mereka adalah Syarif Hidayatullah atau Sunan Gunung Jati; Sultan Hasanuddin atau Pangeran Sabakingkin 1552-1570; dan Maulana Yusuf atau Pangeran Pasareyan 1580-1585.

Pada masa puncak perkembangannya, Kesultanan Banten semakin menjadi pusat penyebaran Islam dan pusat pendidikan Islam. Banyak orang dari luar Banten belajar Islam ke berbagai pesantren di Banten. Salah satu pesantren besarnya adalah Kesunyatan yang memiliki masjid dianggap paling tua dari Masjid Agung Banten. Pada masa Maulana Muhammad yang terkenal sangat shaleh dan banyak menulis kitab sebagai bentuk kepeduliannya terhadap pendidikan agama Islam dan kesinambungan pelaksanaan pendidikan Islam. Pendidikan Islam tersebut semakin pesat perkembangannya pada abad ke 16-17 masehi, terutama dalam masa pemerintahan Sultan Agung Tirtayasa (1651-1672).

Bahkan, sebagai upaya untuk memperkuat mental dari prajurit Banten, didatangkan guru-guru agama dari Aceh, Arab, dan daerah lainnya. Salah seorang guru tersebut adalah seorang ulama besar dari Makassar yaitu Syekh Yusuf yang bergelar Tuanta Salamaka atau Syekh Yusuf Taju Khalwati, yang kemudian dijadikan mufti agung sekaligus guru dan menantu Sultan Ageng Tirtayasa.4

3 Utomo et al., Atlas sejarah Indonesia, 83.

4 Ibid., 83. 
Sisi lain, perlawanan rakyat Indonesia juga semakin militan menentang penjajah Belanda, dan dinamika penyebaran agama Kristen semakin dirasakan masyarakat terutama di awal abad 18. Tidak hanya beranggapan jika orang-orang Belanda sebagai musuh Islam dan kaum muslimin, tetapi juga beranggapan negatif pada orang Islam sendiri yang menyekolahkan anak-anaknya di sekolah Belanda sebagai upaya mengkafirkan anak. Hal ini menyebabkan ada beberapa ulama yang berfatwa haram menyekolahkan anak di sekolah Belanda. Andaipun tidak dihukumkan haram, paling tidak sudah dianggap melanggar dari ajaran Islam. Karena, jika sekolah di sekolah Belanda, otomatis harus memakai seragam Belanda yang menggunakan dasi dan atribut pakaian lain ala Belanda. Menyahuti fenomena ini, ulama dan kaum muslimin Banten mendirikan sekolah yang sesuai dengan kebutuhan masyarakat. Sekolah Islam dimaksud, dibahas setelah membahas peran dan kedudukan ulama di Kesultanan Banten berikut.

\section{Peran dan Kedudukan Ulama di Kesultanan Banten}

Peran dan kedudukan kyai di Banten memiliki status yang dihormati oleh masyarakat. Kehidupan masyarakat yang religius didasarkan kepada suatu kesakralan Tuhan, sehingga keamanan pun dipandang memiliki hubungan yang erat dengan kekuasaan di atasnya, menjadikan masyarakat Banten memiliki ikatan lebih erat terhadap tokoh-tokoh agama dalam memandu kehidupan pribadi dan kehidupan bermasyarakat.

Berdasarkan perannya, kyai di Banten sering dibedakan menjadi "kyai kitab" dan "kyai hikmah." Kyai kitab adalah istilah yang ditujukan kepada kyai atau guru yang banyak mengajarkan ilmu-ilmu secara tekstual Islam, khususnya yang dikenal dengan nama kitab kuning. Seperti kitab-kitab tafsir al-Qur'an, kitab-kitab hadits, kitab-kitab fiqh dan ushul fiqh, kitab-kitab akidah akhlak serta kitab-kitab gramatika Bahasa Arab. Sedangkan "kyai hikmah” adalah kyai yang mempraktekkan ilmu magis Islam, yakni yang mengajarkan wirîd, zikr dan râtib, untuk keperluan praktis seperti permainan debus, pengobatan, kesaktian dan kewibawaan. Meskipun demikian, pembedaan tersebut pada prakteknya tidak memisahkan secara tegas. Namun, banyak juga kyai yang mengombinasikan kedua peran tersebut dengan campuran yang berbeda-beda. 
Peran keagamaan kyai di Banten dapat dirincikan sebagai berikut:

a. Guru Ngaji. Peran awal kyai adalah mengajarkan membaca al-Quran dengan 'ilm tajwîd'. Tahapan berikutnya mengajarkan beberapa metode membaca alQuran dengan suara merdu dan lagu yang indah untuk para qâri dan qâriah yang berbakat suara bagus. Qâri dan qâriah juga diajarkan aliran-aliran atau madzhab-madzhab pembacaan ayat-ayat al-Qur'an.

b. Guru Kitab. Santri yang sudah lancar membaca ayat-ayat al-Quran, dilanjutkan dengan belajar kitab-kitab Islam klasik yaitu kitab kuning. Ini merupakan tugas utama kyai di pesantren, terutama karangan ulama fiqh yang bermadzhab Syafi'i.

c. Guru Tarekat. Seorang kyai yang kharismatik, selain mengajarkan kitab kuning, juga mengajarkan praktek tarekat. Hal tersebut juga dikuatkan dengan tokoh utama dalam Serat Centhini, Jayengresmi alias Among Raga yang berguru ke sebuah perguron di Karang, pembimbingnya seorang guru yang berasal dari Arab bernama Syaikh Ibrahim bin Abu Bakar, yang lebih dikenal sebagai Ki Ageng Karang. ${ }^{5}$ Wajar apabila para tarekat sudah sangat dikenal di lingkungan istana Kesultanan Banten semenjak awal didirikannya kesultanan itu. Pendiri kerajaan Banten Maulana Hasanuddin, telah dibai'at untuk menganut dan mempraktekkan wirid Tarekat Naqsabandiyah. ${ }^{6}$

d. Guru Ilmu Hikmah. Para kyai yang menjadi mursyid suatu tarekat tidak hanya dikenal sebagai pemimpin atau guru tarekat, tetapi juga dikenal sebagai guru ilmu hikmah. Banten memiliki reputasi yang cukup dikenal sebagai daerah tempat bersemayamnya ilmu-ilmu hikmah, sehingga tidak sedikit orang Banten yang memanfaatkan reputasi ini dengan bertindak sebagai juru ramal, pengusir setan, kedudukan dan perlindungan supranatural serta kedamaian jiwa. Kyai yang dikenal sebagai guru ilmu hikmah di Banten adalah Ki Armin (K.H. Muhamad Hasan Amin) dari Cibuntu Pandeglang. Beliau adalah anak oleh saudara (keponakan) dari Kyai Asnawi Caringin, guru Tarekat Qodariyyah wa Naqsabandiyah yang sangat terkenal di Banten.

5 Robert N. Bellah, Beyond Belief: Esai-Esai Tentang Agama Di Dunia Modern (Jakarta: Paramadina dan The Ford Foundation, 2000), 26.

6 Ibid., 265. 
Kyai lain yang juga dikenal memiliki ilmu hikmah adalah Ki Dimyati, yang memimpin sebuah pesantren di Cisantri Pandeglang.

e. Mubaligh. Seorang kyai tidak hanya mengajarkan kitab-kitab klasik di pesantren, tetapi aktif juga melakukan ceramah agama dan khutbah kepada masyarakat dengan berkeliling, sehingga disebut dengan mubâligh (orang yang menyampaikan pesan agama Islam). Cara ini disadari turut memberikan pengaruh besar meningkatkan kehidupan keagamaan rakyat Banten.

Mengamati paparan tentang peran dan kedudukan ulama di Banten sebagaimana paparan di atas, jelas terlihat bahwa ulama di Kesultanan Banten memiliki peran yang multifungsi, yaitu sebagai penyampai ajaran agama Islam dan keagamaan Islam. Sementara kedudukan mereka, tidak hanya sebagai orang yang dihormati, tetapi juga sebagai orang yang berkuasa di Kesultanan Banten. Sebagai buktinya, tergambar bagaimana kiprah yang dilakukan oleh penguasa Kesultanan Banten, mulai dari sebagai pendidik, penulis buku agama, pembentuk semangat jihad, pemotivasi keamanan dan pemimpin Banten. Selain sultan yang memimpin Banten dan menyebarkan agama Islam, banyak tokoh muslim lainnya yang peduli dengan pendidikan Islam, sebagaimana uraian berikut.

\section{Tokoh Pendidikan Islam Banten}

\section{a. Syaikh Nawawi Al-Bantani Al-Jawi}

Syekh Nawawi al-Bantani al-Jawi yang memiliki nama lengkap Abdullah al-Mu'thi Muhammad Nawawi bin Umar al-Tanari al-Bantani alJawi, kelahiran tahun 1813 di Desa Tanara, Kecamatan Tirtayangasa, Serang, Banten, Jawa Barat. Kitab kuning karangannya menjadi rujukan utama berbagai pesantren dalam dan luar negeri. Setelah ditunjuk sebagai pengganti Imam Masjidil Haram yaitu Syaikh Khâtib al-Minagkabawi, namanya semakin termashur, tidak hanya di Mekah dan Madinah, tetapi juga Mesir dan lainnya. Tidaklah mengherankan jika Mesir merupakan negara pertama yang mendukung terhadap Indonesia agar merdeka.

Syekh Nawawi al-Bantani al-Jawi berhaji dan berguru kepada sejumlah ulama terkenal di Mekah sejak berusia 15 tahun, seperti: Syaikh Khâtib al-Sambasi; Abdul Ghani Bima; Yusuf Sumbulaweni; Abdul Hamîd 
Daghestani; Syaikh Sayyid Ahmad Nahrawi; Syaikh Ahmad Dimyati; Syaikh Ahmad Zaini Dahlan; Syaikh Muhammad Khatib Hambali; dan, Syaikh Junaid Al-Betawi. Ilmu yang didapat ditularkan kepada orang lain. Adapun muridnya yang menjadi ulama di antaranya: K.H. Hasyim Asy'ari (Pendiri Nahdhatul Ulama); K.H. Ahmad Dahlan (Pendiri Muhammadiyah); K.H. Khalil Bangkalan; K.H. Asnawi Kudus; K.H. Tb. Bakrie Purwakarta; dan, K.H. Arsyad Thawil.

Setelah pulang ke Indonesia dari tiga tahun bermukim di Mekah, Syekh Nawawi al-Bantani al-Jawi menyaksikan banyaknya ketidakadilan dan penindasan dari Pemerintah Hindia Belanda, akibat dari umat yang masih mau dibodohi. Segera beliau keliling Banten mengobarkan semangat jihat untuk melakukan perlawanan terhadap penjajah. Aksi tersebut menjadikan Pemerintah Belanda membatasi garak-geriknya, dilarang berkhutbah, bahkan dituduh sebagai pengikut Pangeran Diponegoro yang ketika itu memang sedang mengobarkan perlawanan terhadap penjajahan Belanda (1825-1830).

Kepakaran berfikir dan aksi Syekh Nawawi al-Bantani al-Jawi banyak mendapatkan gelar, di antaranya: Doktor Ketuhanan, diberikan oleh Snouck Hourgronje; al-Imam wa al-Fahm al-Mudaqqiq (Tokoh dan pakar dengan pemahaman yang sangat mendalam), diberikan oleh kalangan Intelektual masa itu; al-Sayyid al- 'Ulama al-Hijâz (Tokoh ulama Hijaz). Sementara para ulama Indonesia menggelarinya sebagai Bapak Kitab Kuning Indonesia.

Keintelektualannya terbukti dengan menulis kitab: fiqih, tauhid, tasawwuf, tafsir, dan hadis, yang berjumlah lebih dari 115 kitab. Ulama asal Mesir, Syaikh 'Umar 'Abdul Jabbâr dalam kitabnya "al-Durûs min Mâdhi alTa'lîm wa Hadlirih bi al-Masjidil al-Harâm” (beberapa kajian masa lalu dan masa kini tentang Pendidikan Masa kini di Masjid Haram) menulis bahwa Syaikh Nawawi sangat produktif menulis. Sebagian dari karya-karya Syaikh Nawawi adalah: al-Tsamâr al-Yâni'ah syarah al-Riyâdl al-Badî'ah; al-'Aqd al-Tsamîn syarah Fath al-Mubîn; Sullam al-Munâjah syarah Safinah alShalâh; Salâlim al-Fadhlâ' syarah Mandhûmah Hidâyah al-Azkiyâ'; Qâmi'u al-Thugyân syarah Mandhûmah Syu'bu al-Imân; al-Tafsir al-Munîr li al- 
Mu'âlim al-Tanzîl al-Mufassir 'an wujûh mahâsin al-Ta'wil musammâ Murâh Labîd li Kasyafi Ma'nâ Qur'an Majîd; Kasyf al-Marûthiyyah syarah Matan al-Jurumiyyah; Fath al-Ghâfir al-Khathiyyah syarah Nadham alJurumiyyah musammâ al-Kawâkib al-Jaliyyah; Nur al-Dhalâm 'ala Mandhûmah al-Musammâh bi 'Aqîdah al-'Awwâm; al-Durrur al-Bahiyyah fi syarah al-Khashâish al-Nabawiyyah.

Karya beliau dinilai lebih praktis oleh para pakar ketimbang matan yang dikomentarinya. Misalnya di bidang Ilmu Akidah: Tîjân al-Darâry; Nûr al-Dhalam; Fath al-Majîd. Sementara dalam bidang Ilmu Hadis misalnya: Tanqih al-Qaul. Bidang Ilmu Fiqih yakni Sullam al-Munâjah; Nihâyah alZain; Kâsyifah al-Sajâ. Adapun Qâmi’u al-Thugyân; Nashâih al-'Ibâd; dan, Minhâj al-Raghibi merupakan karya tasawwuf.

\section{b. K.H. Asnawi Caringin Banten}

K.H. Asnawi lahir sekitar tahun 1850 di Kampung Caringin, putra dari Abdurrahman dan Ratu Sabi'ah. Keturunan ke-17 dari Sultan Ageng Mataram atau Raden Fattah. Sejak umur 9 tahun---ayahnya telah mengirimnya ke Mekah untuk memperdalam agama Islam dan belajar dengan ulama kelahiran Banten yang telah termasyhur yaitu Syech Nawawi alBantani. Gurunya K.H. Asnawi memintanya pulang ke Indonesia untuk menyiarkan Islam setelah dirasa ilmu yang dimilikinya memadai.

Sekembalinya dari Mekah, K.H. Asnawi mulai melakukan dakwah ke berbagai daerah, ketinggian ilmu yang dimiliki---menjadikannya terkenal dan jadi panutan di masyarakat Banten. Situasi Tanah air yang masih di kuasai penjajah Belanda dan rusaknya moral masyarakat waktu itu, membuat K.H. Asnawi sering mendapat ancaman dari pihak yang merasa kebebasannya terusik. Banten yang terkenal dengan jawaranya yang memiliki ilmu kanuragan, dapat di taklukkan berkat kegigihan dan perjuangan K.H. Asnawi.

K.H. Asnawi juga terkenal sebagai ulama dan jawara yang sakti dan sangat di segani oleh penjajah Belanda. Dakwahnya yang mengobarkan semangat nasionalisme anti penjajah, menjadikannya ditahan di Tanah Abang dan diasingkan ke Cianjur oleh Belanda selama kurang lebih satu tahun. 
Tetapi K.H. Asnawi mendapat dukungan penuh dari rakyat dan para ulama lainnya, seperti para bangsawan dan para jawara.

Selama di pengasingan, K.H. Asnawi tetap mengajarkan al-Quran dan tarekat kepada masyarakat di sekitar. Sekitar tahun 1884, setelah keadaan dirasa aman, K.H. Asnawi kembali ke Caringin dan mendirikan Madrasah Masyarikul Anwar serta mendirikan Masjid Salafiah Caringin. Kayu masjid tersebut berasal dari sebuah pohon di Kalimantan. Dahulu pohon tersebut tidak bisa di tebang kalaupun bisa di tebang beberapa saat pohon tersebut muncul kembali, hingga akhirnya K.H. Asnawi memohon kepada Allah swt agar diberi kekuatan, akhirnya pohon tersebut dapat di tebang serta kayunya dibawa K.H. Asnawi ke Caringin untuk membangun Masjid. Arsitek dan ornamen lokal mendominasi bangunan masjid. Sungguhpun demikian, juga mengolaborasinya dengan arsitektur asing khusus pada bentuk jendela dan pintu dalam dengan ukuran lebih besar juga terdapat pilar-pilar yang mengelilingi masjid.

Pada tahun 1937 beliau tutup usia, meninggalkan 23 anak dari lima Istri (Hj. Ageng Tuti halimah, Hj. Sarban, Hj Syarifah, Nyai Salfah dan Nyai Nafi'ah), dimakamkan di Masjid Salfiah Caringin.

\section{c. K.H. Mas Abdurahman}

K.H. Mas Abdurahman lahir pada tahun 1868 di Kampung Janaka, tepatnya di lereng Gunung Haseupan di Distrik Labuan Kawedanan Caringin Kabupaten Pandeglang Banten. Putra dari K. Mas Djamal al-Djanakawi. Gelar "Mas" merupakan gelar kehormatan yang diberikan turun temurun, berasal dari nama seorang senopati Pajajaran bernama Mas Jong dan Agus Ju. Mereka adalah tangan kanan Raja Pajajaran bernama Pucuk Umun. Ketika Kerajaan Pajajaran ditaklukan oleh Sultan Hasanudin, Pucuk Umun melarikan diri ke selatan. Sedangkan Senopati Mas Jong dan Agus Ju menyerahkan diri kepada Sultan Hasanudin. Kemudian Mas Jong dan Agus Ju memeluk agama Islam, dan mendapat kedudukan penting sebagai senopati Kasultanan Banten dengan gelar kehormatan Ratu Bagus Ju dan Kimas Jong. 
Semenjak runtuhnya Kesultanan Banten, para ulama dan keluarga besar Kesultanan Banten mengasingkan diri, menjauhkan diri dari keramaian kota, termasuk keturunan Mas Jong dan Agus Ju pergi mininggalkan istana kesultanan ke pedalaman di Lereng Gunung Haseupan, tepatnya Dusun Janaka dalam rangka menyusun kembali kekuatan untuk bergerilya melawan Belanda, termasuk di antaranya K. Mas Djamal al-Djanakawi ayahnya K.H. Mas Abdurahman. Saat itu kesultanan pun sudah berubah menjadi Keresidenan Banten yang dipimpin oleh seorang residen Bangsa Belanda. Para ulama yang awalnya secara resmi bertugas sabagai bagian dari pelaksana kesultanan, sangat diawasi bahkan di kejar-kejar, dianggap sabagai pembangkang dan pemberontak terhadap Belanda.

K. Mas Djamal al-Djanakawi yang berada di pedalaman, tetap memperhatikan terhadap masa depan putranya. Selain mengajarkan al-Quran sendiri juga menitipkannya berguru kepada K.H. Shahib di Kampung Kadupinang. Setiap belajar diantar ayahnya dengan cara digendong, selain jarak yang cukup jauh, juga belum ada alat transportasi. Setelah cukup usia, barulah dititipkan di Pondok Pesantren al-Quran di Serang di bawah bimbingan K.H. Ma'mun. Setelah berhasil menyelesaikan belajar di pesantern al-Qur'an pada tahun 1905, berangkat ke Mekah untuk berhaji dan menuntut ilmu serta berziarah ke makam ayahnya yang wafat dan dimakankan di Mekah.

K.H. Mas Abdurahman berguru kepada: Syech Nawawi Al-Bantani berasal dari Tanahara yang terkenal dengan kitab tafsirnya dan Syech Achmad Chotib berasal dari Minangkabau yang terkenal dengan ilmu tasawufnya, K.H. Hasyim Asy'ari dari Surabaya yang kemudian dikenal sebagai pendiri Nahdlatul 'Ulama tahun 1926 dan K.H. Ahmad Dahlan sebagai pendiri Muhammadiyah tahun 1912. Penguasaannya terhadap ilmu bahasa Arab, fiqh, usul fiqh, nahu, sharaf, balaghah, tafsir, ilmu ushul, tasawuf, dan lain-lain, menjadikannya diangkat sebagai Badak (asisten dosen) pengajian di Masjidil Haram. 
Secara umum masyarakat Banten jarang mendapat kesempatan belajar menuntut ilmu agama Islam semenjak para ulama meninggalkan kesultanan, tetapi tetap diuntungkan dengan kondisi masyarakat Banten yang telah memiliki jiwa keislaman, dibuktikan dengan tiap keluarga merasa berkewajiban mewariskan ilmu agama kepada generasinya, sekalipun masih berbaur dengan takhayul, bid'ah dan khurafat. Melihat keadaan pendidikan yang semakin tidak berpihak pada masyarakat pribumi, seakan memaksa para ulama untuk mencari solusi. Akhirnya, para ulama, kyai, guru ngaji dan masyarakat bermusyawarah di Kampung Kananga, dipimpin oleh K.H. Entol Mohammad Yasin dan K.H. Tb. Mohammad Sholeh, menghasilkan keputusan untuk meminta dan menyurati K.H. Mas Abdurahman yang sedang menuntut ilmu di Mekkah untuk kembali ke Banten.

Setelah menimbang manfaatnya, K.H. Mas Abdurahman membatalkan kepercayaan dirinya yang diminta menjadi Badak, dan memutuskan untuk kembali ke Indonesia. Peristiwa ini terjadi sekitar tahun 1910. Kehadiran kyai muda yang penuh semangat dianggap berhasil memperjuangkan masyarakat Banten dari kebodohan, dan berjuang mengadakan pembaharuan Islam bersama kyai-kyai di Banten saat itu. Selanjutnya, K.H. Mas Abdurahman dinikahkan dengan putri K.H. Tb. Mohammad Sholeh yakni Nyi. Enong.

Memperhatikan uraian di atas, tokoh pendidikan Islam yang peduli dengan penyebaran Islam di Banten, memiliki tekat dan semangat yang luar biasa. Pada zaman itu sudah menulis berbagai buku agama Islam, dan menjadi hasil karya yang fenomenal, karena tidak hanya digunakan oleh jamaah yang ada di sekitar Banten, tetapi juga menjadi rujukan pendidikan sampai ke luar negeri. Para tokoh juga harus menjuang tidak hanya memberantas kebodohan, tetapi juga harus berjuang melawan penjajah yang menyebabkan kebodohan.

\section{Lembaga Pendidikan Islam Banten}

Pendidikan masyarakat Banten semakin terpuruk di bawah kekuasaan Belanda saat itu. Pendidikan yang didirikan Pemerintah Belanda tidak terjangkau oleh masyarakat pribumi. Selain jumlah yang sangat sedikit (hanya ada di kota- 
kota kewadanaan saja), juga syarat untuk dapat belajar sangat berat, dan cenderung sengaja dipersulit dengan bermacam persyaratan. Karena memang tujuan sesungguhnya dari didirikannya sekolah oleh Belanda, hanyalah untuk memenuhi pekerja ambtenar yang jumlahnya tidak perlu banyak. Rakyat pribumi sebagian besar hanya dibutuhkan sebagai pekerja kasar yang tidak ada hubungannya dengan menuntut ilmu di sekolah, dalam arti yang penting asal memiliki tenaga yang kuat saja.

Pondok Pesantrenlah pendidikan Islam yang masih ada dan diselenggarakan oleh para ulama/kyai, inipun dilaksanakan secara individual dan tradisional, yang dalam pelaksanaannya sangat terbatas. Terbatas dari segi sarana, sumber dana, pengelolaan atau manajemennya, ditambah lagi dengan kondisi yang tidak aman dari berbagai pengawasan pemerintahan Belanda. Pemerintah Belanda yang menjajah beranggapan bahwa kharisma keagamaan yang tersimpan dalam jiwa para ulama/kyai, serta powernya yang masih tinggi di masyarakat, sangat menjadi alasan untuk selalu diwaspadai, dan dikebiri pihak penjajah. Mereka menganggap ini hal yang membahayakan, karena para ulama/kyai akan dapat membawa masyarakat apabila suatu ketika ada peluang, dipastikannya akan dapat mengobarkan semangat melawan terhadap pemberontak yaitu Pemerintah Belanda.

Selain karena tradisi menjalin hubungan dengan pusat ajaran Islam yang telah giat dilakukan sejak masa-masa awal Kesultanan Banten, kesadaran keagamaan yang kuat terhadap ajaran Islam ini juga tentu tidak terlepas dari proses pendidikan yang dilaksanakan oleh para penyebar Islam. Mereka secara intens menanamkan ajaran-ajaran Islam kepada penduduk Banten hingga melahirkan orang-orang Banten yang disebut oleh pemerintah kolonial sebagai fanatik, atau menurut lafal Bantennya "orang panatik". Pendidikan tersebut dilaksanakan di lembaga-lembaga seperti langgar, masjid, pesantren atau di rumah-rumah seorang tokoh agama. Sedangkan lembaga pendidikan yang disebut madrasah tidak dikenal hingga dekade pertama awal abad XX. Berbagai subsidi terhadap sekolah dan lembaga misi, kini mulai diberikan secara terang-terangan. ${ }^{7}$

7 Alwi Shihab, Membendung Arus: Respons Gerakan Muhammadiyah terhadap Penetrasi Misi Kristen di Indonesia (Mizan, 1998), 43-44. 
Pesantren yang menjadi basis pendidikan agama masyarakat muslim tidak mendapatkan perhatian sama sekali. ${ }^{8}$ Pemerintah berargumen bahwa hal itu dilakukan untuk menjaga netralitas terhadap agama apapun sebagaimana secara formal tertuang dalam konstitusi Belanda tahun 1855 dan Peraturan Pemerintah Hindia Belanda tahun 1871. Akan tetapi klaim tersebut tidak benar, karena pada saat yang sama pemerintah membantu pembangunan Sekolah Teologi Kristen. ${ }^{9}$

Pendidikan di Banten dengan sistem modern yang didirikan oleh kolonial baru dibuka pada tahun 1910. Keterlambatan pendirian mengakibatkan jumlah anak-anak Banten yang masuk ke dalam sistem persekolahan ini adalah jumlah yang paling rendah di seluruh Jawa. Pada tahun 1916, empat HIS di Banten masing-masing memiliki murid sebagai berikut: di Serang, 189 laki-laki dan 46 perempuan; di Cilegon, 91 laki-laki dan 29 perempuan; di Pandeglang, 147 lakilaki dan 23 perempuan; dan di Rangkasbitung, 136 laki-laki dan 40 perempuan. ${ }^{10}$ Penyebab lainnya adalah rasa enggan yang mengidap di masyarakat Banten untuk memasukkan anak-anaknya ke lembaga pendidikan Belanda. Pandangannya, menyekolahkan anak-anak ke sekolah yang didirikan oleh kaum kafir itu adalah haram, atau setidaknya tidak dianjurkan dalam Islam. ${ }^{11}$ Jadi, lembaga pendidikan Islamlah yang menjadi pilihan utama orang tua dalam mendidik anak-anaknya pada saat itu. Namun di sisi lain, pendidikan Islam sudah saatnya untuk menawarkan pola pendidikan yang lebih maju, baik dalam hal kelembagaan, struktur materi, maupun metodenya, sehingga dapat mengimbangi sekolahsekolah ala Belanda.

Steenbrink, dari hasil penelitiannya menemukan bahwa awal abad XX, telah terjadi apa yang disebut sebagai kebangkitan, pembaharuan (renaissance) atau bahkan pencerahan. ${ }^{12}$ Bagi tokoh-tokoh pembaharu pendidikan, kiranya

8 Karel A. Steenbrink, Pesantren, madrasah, sekolah: pendidikan Islam dalam kurun moderen (Lembaga Penelitian, Pendidikan dan Penerangan Ekonomi dan Sosial, 1986), 8-9.

9 Sumarsono Mestoko and Indonesia Departemen Pendidikan dan Kebudayaan, Pendidikan di Indonesia dari jaman ke jaman (Departemen Pendidikan dan Kebudayaan, 1985), 80-81.

10 Wardiman Djojonegoro, Lima puluh tahun perkembangan pendidikan Indonesia (Departemen Pendidikan dan Kebudayaan, 1996), 64.

11 Rahayu Permana, “Kyai Haji Syam'un (1883-1949): Gagasan Dan Perjuangannya” (PPs

Fakultas Ilmu Pengetahuan Budaya UI, 2004), 29.

12 Steenbrink, Pesantren, madrasah, sekolah, 26. 
senantiasa sebagai aspek yang strategis untuk membentuk sikap dan pandangan keislaman masyarakat. Dari pandangan seperti inilah terwujud lembaga pendidikan Islam baru yang di namakan madrasah. ${ }^{13}$ Pemerintah Belanda menyadari jika tidak bisa melawan arus masyarakat dalam hal memilih sekolah untuk putra putrinya, akhirnya memilih untuk merakyatkan sekolah-sekolah sekuler kolonial Belanda, juga ikut mendorong lahirnya lembaga pendidikan madrasah saat itu.

Artinya, kekuatan awal berdirinya lembaga pendidikan Islam di Banten, karena emansipasi bangsa Indonesia secara berangsur-angsur. ${ }^{14}$ Berangsur juga para ulama mengadopsi pola pendidikan barat dengan memasukkan materi pelajaran vokasional di lembaga pendidikan Islam. Akhirnya, sekolah Belanda pun sudah mulai dibuka dan diperkenalkan sampai ke lapisan bawah, yang sebelumnya hanya dinikmati secara eksklusif oleh kelompok terpilih saja.

Berdasarkan kenyataan ini umat Islam meresponsnya dengan melakukan analisis logis antara lembaga pendidikan pesantren dengan persekolahan Belanda sehingga melahirkan bentuk lembaga pendidikan Islam yaitu "madrasah". Selain itu juga, lahirnya lembaga pendidikan yang bernama madrasah, juga dimaksudkan untuk menjawab tantangan kolonialisme dan ekspansi Kristen. Madrasahmadrasah tersebut akan diuraikan dalam bahasan berikut.

\section{Madrasah dan Pesantren Mathla'ul Anwar}

\section{a. Pendiri dan latar belakang berdiri}

K.H. E. Moh. Yasin yang baru kembali dari menghadiri rapat yang diselenggarakan di Bogor, oleh para ulama yang mendambakan kehidupan umat yang lebih baik. Gerakan ini dipelopori oleh H. Samanhudi dalam rangka mendirikan Syarikat Dagang Islam (SDI) pada tahun 1908. Beliau mendatangi rekan-rekan ulama yang ada di sekitar Menes, antara lain K.H. Tb. Moh. Shaleh dari kampung Kananga dan beberapa orang kyai lainnya. Tujuan pertemuan tersebut adalah untuk bermusyawarah dan bertukar pikiran,

13 Ibrahim Anis, Al-Mu'jam Al-Wasi't (Kairo: Dar al-Ma“earif, 1972), 280.

14 S. Nasution, Sejarah pendidikan Indonesia (Jemmars, 1983), 16. 
yang akhirnya melahirkan kata sepakat untuk membentuk suatu majelis pengajian yang diasuh bersama.

Akhirnya mengambil keputusan memanggil K.H. Mas Abdurrahman bin K.H. Mas Jamal untuk kembali ke Indonesia. Sebagai Mudir atau direktur sebuah perguruan Islam dalam bentuk madrasah, dan Presiden Bistirnya K.H. E. Moh Yasin dari kampung Kaduhawuk, Menes, serta dibantu oleh sejumlah kyai dan tokoh masyarakat di sekitar Menes. Memulai kegiatan belajar mengajarnya pada tanggal 10 Syawwal 1334 H/9 Agustus 1916 M.

Selengkapnya para pendiri Mathla'ul Anwar adalah: Kyai Moh. Tb. Soleh; Kyai E.H. Moh Yasin; Kyai Tegal; Kyai H. Mas Abdurrahman; K.H. Abdul Mu'ti; K.H. Soleman Cibinglu; K.H. Daud; K.H. Rusydi, E. Danawi; dan, K.H. Mustagfiri.

\section{b. Tujuan Berdiri Mathla'ul Anwar}

Adapun tujuan didirikannya Mathla'ul Anwar adalah agar ajaran Islam menjadi dasar kehidupan bagi individu dan masyarakat. Untuk mencapai tujuan tersebut, maka disepakati untuk menghimpun tenaga-tenaga pengajar agama Islam, mendirikan madrasah, memelihara pondok pesantren dan menyelenggarakan tabligh ke berbagai penjuru tanah air yang pada saat itu masih dikuasai oleh Pemerintah Belanda. Pemerintah kolonial telah membiarkan rakyat pribumi hidup dalam kebodohan, kemiskinan dan keterbelakangan.

\section{c. Sistem Pendidikan Mathla'ul Anwar}

Kegiatan belajar untuk sementara diselenggarakan di rumah seorang dermawan di kota Menes, yang merelakan tempat tinggalnya digunakan untuk tempat belajar bagi umat Islam. Tokoh ini adalah K.H. Mustagfiri. Setelah mendapatkan sebidang tanah wakaf dari Ki Demang Entol Djasudin, yang terletak di tepi jalan raya, dibangunlah sebuah gedung madrasah dengan cara gotong-royong oleh seluruh masyarakat Islam Menes. Sampai kini gedung tersebut masih berfungsi sebagai tempat penyelenggaraan Madrasah Ibtidaiyyah, Sekolah Dasar Islam dan Taman Kanak Kanak Mathla'ul Anwar. 
Gedung tersebut tidak lain ialah pusat perguruan Islam Mathla'ul Anwar yang terletak di kota Menes, Pandeglang.

Pendidikan pesantren modern, yaitu yang mengolaborasi sistem pendidikan umum dan agama juga dibuka untuk mengimbangi dan memenuhi kebutuhan masyarakat saat itu. Model ini tetap dihidupsuburkan, bahkan dikorelasikan dengan sistem sekolah. Kegiatan belajarnya dilakukan waktu pagi, sore dan malam hari di rumah masing-masing, tetap menyelenggarakan pengajian dengan sistem pesantren dan menampung santri yang datang dari berbagai daerah untuk belajar di Madrasah Mathla'ul Anwar.

Santriwan dan santriwati yang telah menyelesaikan pendidikan selama 9 (sembilan) tahun, yaitu tamat dan lulus kelas VII, dikirim ke berbagai tempat/daerah untuk mendakwahkan ajaran Islam dalam bentuk baru, yaitu mendirikan Madrasah Mathla'ul Anwar cabang Menes, untuk pertama kalinya selalu diantar oleh pengurus Mathla'ul Anwar Menes. Mereka diberi bisluit atau surat tugas mengajar dari Presiden of Bestur Mathla'ul Anwar. Bermodalkan ghirah dan semangat keimanan dan keyakinan terhadap janji Allah swt dalam QS. 47:7:, yang artinya:

"Hai orang-orang mukmin, jika kamu menolong (agama) Allah, niscaya Dia akan menolongmu dan meneguhkan kedudukanmu".

Tidaklah mengherankan jika pada tahun 1920-an sampai dengan tahun 1930-an, di Lampung, Lebak, serang (Kepuh), Bogor, Tangerang, Karawang dan tempat-temapat lain, sudah berdiri Madrasah Mathla'ul Anwar cabang Menes, dengan catatan hanya diizinkan menyelenggarakan madrasah sampai kelas IV, dan harus belajar ke Menes untuk melanjutkan kelas V- VII.

\section{d. Madrasah Putri Mathla'ul Anwar}

Madrasah Putri Mathla'ul Anwar didirikan pada tahun 1929 dengan tiga tokoh yang menjadi pimpinannya yaitu: Nyi. H. Jenab binti Yasin, Nyi Kulsum, dan Nyi Aisyah, di samping kegiatan belajar mengajar di madrasah dan pesantren bagi murid-murid, juga setiap hari Kamis tiap pekan seluruh guru yang mengajar diwajibkan mengikuti pengajian yang diselenggarakan di masjid Soreang, Menes, di situ K.H. Mas Abdurrahman menetap dan 
sekaligus sebagai sentral pengajian. Tujuannya adalah dalam rangka memperluas dan memperdalam ilmu Islam, dimaksudkan agar para kyai pimpinan Mathla'ul Anwar dapat berfikir kritis dan berwawasan luas karena sudah memiliki berbagai pandangan dan bermacam sumber ilmu.

\section{e. Pendanaan Madrasah Mathla'ul Anwar}

Bergotong royong dalam membangun dan memelihara Madrasah Mathla'ul Anwar, merupakan ciri khas pelaksanaan pendidikannya, baik tenaga pengajarnya, pengelolanya, sampai pada sumber dananya. Misalnya menghimpun sedekah jariyah, wakaf dan jimpitan (beras remeh), yang diselenggarakan oleh jama'ah majlis ta'lim ibu-ibu. Caranya, setiap kali hendak masak nasi diambil satu genggaman kecil seukuran satu sendok makan dari beras yang akan dimasak dan ditampung dalam tempat tersendiri yang sudah disiapkan.

Beras yang terkumpul di masing-masing keluarga, akan diambil oleh petugas, biasanya diberikan kesempatan kepada janda miskin, dengan maksud untuk mendapat imbalan sepuluh persen dari hasil pungutannya. Selanjutnya, disetorkan kepada para kader yang mengikuti pengajian setiap hari Kamis, dan menyerahkan lagi kepada koordinator pusat Mathla'ul Anwar yang sudah ditunjuk.

Tidak terasa tetapi pasti, itulah yang dirasakan masyarakat pada saat mempertahankan dan mengembangkan Madrasah Mathla'ul Anwar saat itu, akhirnya mampu menghimpun suatu kekuatan. Selanjutnya, ada juga yang tidak bisa dilupakan dalam sejarah, yaitu adanya beberapa bidang tanah yang dibeli dari hasil pungutan beras jimpitan (beras remeh) dan hingga kini tempat itu dinamakan "kebon remeh" milik Mathla'ul Anwar.

\section{f. Madrasah Arabiah (Sekolah Arab) Mathla'ul Anwar}

Pada tahun 1940 didirikan Madrasah Arabiah (Sekolah Arab) yang khusus memberi pelajaran bahasa Arab, untuk itu didatangkan seorang guru dari Salatiga yaitu K.H. Humaedi di samping itu beberapa pemuda dikirim ke Jakarta (sekolah Jamiatul Khaer) untuk calon-calon guru, dan untuk 
mempelajari ilmu Falak didatangkan guru dari Pekalongan (K.H. Syabrawi dan diadakan kursus ilmu falak bagi guru-guru Mathla'ul Anwar).

\section{g. Pesantren Mathla'ul Anwar}

Sebagai upaya untuk menampung peserta didik yang datang dari berbagai daerah, didirikanlah pondok-pondok pesantren di sekitar Menes, yang paling besar berada di Kananga, pimpinan K.H. Tb. Ahmad, merupakan alumni pertama pendidikan di Mathla'ul Anwar. Para santri yang mondok di Kananga kebanyakan berasal dari Bogor, Tangerang, Lampung dan lain-lain, jumlah sampai ratusan santri.

Kananga adalah satu kampung di kaki gunung Pulosari, merupakan tempat cikal bakal Mathla'ul Anwar, sebab di situlah K.H. Tb. Moh. Sholeh tinggal, dan setibanya K.H. Mas Abdurrahman dari Mekah tinggal di Kananga dan menikah dengan putri dari K.H. Tb. Moh. Sholeh, selanjutnya pindah ke Soreang Menes, dan di Soreang inilah dibangun pesantren. K.H. E. Muhamad Yasin adalah putra dari seorang jaksa, yang intelektual tinggi dan berwawasan luas.

\section{h. Lahirnya Statuten Mathla'ul Anwar}

Peristiwa pemberontakan rakyat terhadap pemerintahan Belanda pada tahun 1926 di Menes dan Labuan, tanpa disadari oleh para tokoh dan pimpinannya, telah membuat Mathla'ul Anwar bertambah besar dan meluas. Pemberontakan yang oleh pihak Belanda disebut sebagai pemberontakan komunis, menyebabkan para tokoh dan pimpinan Mathla'ul Anwar selalu dicurigai dan diawasi oleh aparat pemerintahan, terutama pihak P.I.D (polisi rahasia kolonial Belanda).

Hal ini terjadi karena di antara pelaku pemberontakan terdapat tokoh dan orang-orang Mathla'ul Anwar. Meskipun mereka tidak dalam kapasitasnya sebagai tokoh dan warga Mathla'ul Anwar, tetapi dalam kedudukannya sebagai anggota Serikat Islam. Sebagian dari mereka bahkan ada pula yang dibuang ke Boven Degul, Tanah Merah Irian, antara lain: K. Abdulhadi Bangko; Khusen Cisaat; dan lain-lain. 
Adanya pengawasan dan kecurigaan yang amat ketat di Pandeglang, khususnya di Menes dan Labuan, aktivitas para pimpinan Mathla'ul Anwar di daerah tersebut menjadi berkurang dan terpaksa harus sangat berhati-hati. Para kyai dan ulama Mathla'ul Anwar kemudian bergerak menyebarluaskan Mathla'ul Anwar ke luar daerah, mengirimkan kader-kader dan para abituren (lulusan) Madrasah Mathla'ul Anwar Menes ke daerah-daerah di luar Pandeglang, di antaranya ke kabupaten Lebak, Serang, Tangerang, Bogor, Karawang dan di Keresidenan Lampung.

Jumlah madrasah Mathla'ul Anwar sudah mencapai 40 (empat puluh) buah pada tahun 1936, yang tersebar di tujuh daerah sebagaimana ditulis pada uraian sebelumnya. Pada waktu itu perhatian terhadap Mathla'ul Anwar tidak lagi terbatas dari kalangan kaum pelajar (intelektual) pun mulai ikut berpartisipasi aktif. Sesuai dengan perkembangan Mathla'ul Anwar, maka timbullah gagasan-gagasan untuk meningkatkan kualitas perkembangan organisasinya, baik yang bersifat hard maupun soft manajemennya.

\section{Pondok Pesantren al-Khairiyah ${ }^{15}$}

Pondok Pesantren al-Khairiyah didirikan oleh Syam'un bin Alwiyah (Brigjen TNI) pada tahun 1916 di Kampung Citangkil, Desa Warnasari, Kecamatan Pulomerak, Kabupaten Serang, Jawa Barat. Awal keberadaannya termotivasi dari keinginan masyarakat sekitar untuk bisa mengaji dan ingin mengetahui tentang keislaman. Masyarakat sekitarnya didominasi oleh petani, nelayan dan pedagang, maka sistem pengajiannya pun lebih bersifat tradisional dengan metode wetonan dan sorogan.

Awalnya pondok ini bernama "Pondok Pesantren Citangkil" sesuai dengan nama desa di mana pesantren berada. Kemudian pada tahun 1925 berubah menjadi Madrasah al-Khairiyah dengan tingkatan pendidikan antara lain: Kelas Nol (Awaliyah), Kelas Setengah (Tahdiriyah), Kelas I-VII. Kelas Nol sampai Kelas Setengah adalah tingkat persiapan. Kelas I sampai VII tingkat Ibtidaiyah, kemudian dibentuk pula Madrasah Muallimin (Sekolah Guru) sebagai lanjutan

15 Direktorat Pendidikan Diniyah dan Pondok Pesantren Departemen Agama RI, Pendidikan Islam, 2007, 18. 
dari tingkat Ibtidaiyah, Madrasah Mu'allimin mempunyai dua kelas (kelas I \& II), masing-masing kelas memakan waktu satu tahun.

Pada tahun 1930 Pesantren ini mengalami perubahan, yaitu: Tingkat Dasar (MI selama enam tahun). Tingkat menengah (MTs selama tiga tahun), dan tingkat atas (Mu'allimin selama dua tahun). Pengembangan pendidikan terjadi pada enam tahun kemudian yaitu tahun 1936, dengan didirikannya sekolah umum yang dibina langsung oleh pondok pesantren yaitu HIS (Holandch Inlanch School) yang disebut juga dengan HIS al-Khairiyah Citangkil.

Berdirinya sekolah ini merupakan tandingan sekolah-sekolah umum Belanda, untuk memberikan kesempatan seluas-luasnya bagi rakyat pribumi untuk mengenyam pendidikan umum. Walaupun demikian sekolah ini tetap memiliki identitas keislaman (santri).

Pengelolaan pondok pesantren pada mulanya ditangani langsung oleh pendirinya yang sekaligus sebagai pengasuhnya, sehingga pendidikan yang memadai belum berjalan sempurna, kemudian dibentuklah suatu organisasi yang bernama "Jam'iyah Nahdatus Syubbanil Muslimin" (Perkumpulan Kebangkitan Pemuda Islam), pada tanggal 21 Juni 1931 dengan ketua K.H. Ali Jaya. Organisasi inilah yang kemudian berperan dalam pengembangan pondok pesantren dan madrasah dari pusat sampai ke cabang.

Dua tokoh penting yang perlu dicatat dalam perkembangan al-Khairiyah adalah K.H. Ahmad Sjadeli Hasan, dan K.H. Abdul Fatah Hasan. Tokoh pertama dikenal sebagai salah seorang ahli tafsir Indonesia lulusan dua perguruan tinggi di Timur Tengah, yakni al-Azhar dan Darul Ulum Mesir. Di lingkungan pergerakan Islam, Sjadeli Hasan dikenal sebagai tokoh Masyumi yang memiliki hubungan dekat dengan Mohammad Natsir.

Perdebatan di konstituante tokoh ini juga tercatat sebagai salah seorang pembicara Masyumi. Sementara Abdul Fatah Hasan adalah abituren al-Khairiyah lulusan al-Azhar Mesir, yang memberikan pengaruh sangat besar terhadap perjalanan al-Khairiyah di kemudian hari. Di lingkungan al-Khairiyah Fatah Hasan, dikenal sebagai ulama dan kyai yang berfikiran modern serta memiliki penguasaan ilmu keagamaan yang luas. 
Kegiatan pendidikan dan ciri khas Pondok Pesantren al-Khairiyah sejak awalnya (1925) menerapkan sistem klasikal, tetapi tidak meninggalkan kebiasaan seperti di pondok pesantren salaf, yaitu mengajarkan kitab salaf yang diberikan setiap ba'da shalat Subuh (muhadarah), mufradat setelah shalat Ashar (ilmu alat: nahwu, sharaf, balaghah dan lain-lain) setelah shalat Isya (tafsir, hadis, tauhid, tasawuf, dan lain-lain). Dalam pengajian kitab klasik (kitab kuning ini menggunakan metode bandongan (kolektif) dan metode sorogan (individual).

Materi yang diajarkan di pondok pesantren cenderung memperdalam tafsir/'ulumul Quran, sehingga ini menjadi ciri khas Pondok Pesantren alKhairiyah. Kekhasan ini sangat dipengaruhi oleh keberadaan tenaga ahli lulusan Timur Tengah.

Santri yang menuntut ilmu di pondok pesantren ini ada yang bermukim ada juga yang sebagai santri kalong, maksudnya santri yang datang pada saat ada pembelajaran dan kembali ke rumah masing-masing selesai pembelajaran.

\section{Pesantren dan Madrasah al-Djauharotunnaqiyyah Cibeber}

\section{a. Berdirinya Pesantren dan Madrasah al-Djauharotunnaqiyyah}

Sekitar abad ke-18 M, K.H. Abu Shaleh dan K.H. Burhan (17791813) dari Demak, serta seorang lagi yang bernama K.H. Burhan (17791813) menetap di Cibeber, berdakwah atau mengajarkan pelajaran Agama Islam sampai membuat suatu tempat yang lebih dikenal dengan sebutan pesantren. ${ }^{16}$ Lulusan pesantren dan madrasah ini di antaranya melahirkan alumni hebat sebagai generasi penerus, yaitu: K.H. Madhan (putra K.H. Burhan); K.H. Sachal; K.H. Suyuthi; dan, K.H. Yahya. Mereka inilah yang melanjutkan dakwah di Cibeber dan sekitarnya yang pada waktu itu masih dikenal dengan nama lembaga pendidikan yang disebut pesantren. ${ }^{17}$

Setelah K.H. Madhan wafat, dilanjutkan dengan putranya yaitu K.H. Afifuddin (1846-1860) untuk melanjutkan cita-citanya berdakwah dan

16 Taufik Abdullah, Ensiklopedi Tematis Dunia Islam: Dinamika Masa Kini (Jakarta: PT. Ichtiar Baru Van Houve, n.d.), 37.

17 Diposkan oleh IKBAL CIBEBER, "Sejarah Madrasah Al-Djauharotunnaqiyyah Cibeber," accessed May 22, 2017, http://ikbalcibeber.blogspot.com/2011/01/sejarah-madrasah-aldjauharotunnaqiyyah.html. 
mengajarkan pelajar-pelajar di pesantren yang pada waktu itu masih bersifat sederhana. Dakwahnya dilanjutkan oleh K.H. Abdussalam (1882-1915) putera K.H. Jaya. Sekitar tahun 1915 beliau pergi ke Mekah untuk menunaikan ibadah haji dan bermukim di sana dan menjadi pendidik di Mekah sampai dengan meninggalnya. Setelah itu, dilanjutkan oleh K.H. Abdul lathief.

\section{b. Kepemimpinan K.H. Abdul Lathief di Pesantren}

K.H. Abdul Lathief memiliki obsesi tersendiri, sehingga tidak hanya melaksanakan pembinaan pendidikan keagamaan di masjid, majelis taklim atau pesantren saja, melainkan juga mendirikan madrasah dan pesantren di Cibeber. Beliau mendirikan madrasah bersama kawan-kawannya yang mendapat dukungan masyarakat setempat pada tahun 1924, sebanyak 6 (enam) lokal dengan jumlah tenaga pendidik sebanyak 6 (enam) orang. Madrasah tersebut diberi nama "Tarbiyatul Athfal". ${ }^{18}$ Sebelum mendirikan madrasah tersebut, yaitu sejak tahun 1918 sampai dengan tahun 1924, mengabdikan diri untuk melaksanakan pengajian-pengajian di masyarakat Cibeber dan para santrinya. Tempat pengajiannya adalah di majlis taklim atau serambi mesjid. ${ }^{19}$

Perkembangan selanjutnya, karena tanah yang dibangun untuk madrasah itu kurang luas dan kurang strategis, serta pemandangannya kurang mendukung untuk sebuah lembaga madrasah yang lebih besar, maka K.H. Abdul lathif bermusyawarah dengan tokoh-tokoh masyarakat dan para ulama setempat untuk mendirikan madrasah yang lebih representatif. Akhirnya pada tahun 1931, madrasah tersebut diperluas dan diberi nama "Perguruan Islam al-Djauharotunnaqiyyah", memiliki ruangan sebanyak 10 (sepuluh) lokal. Tanah bangunan gedung tersebut sebagian besar adalah wakaf dari mertuanya yaitu H. Anhar. ${ }^{20}$ Madrasah baru tersebut langsung di bawah asuhan K.H. Abdullatif sendiri, dibantu oleh saudara menantunya K.H. Suchari dan rekanrekannya yang lain.

18 Ibid.

19 Ibid.

20 Ibid. 
Upaya untuk menjalankan kepemimpinan selanjutnya, K.H. Abdullatif dibantu oleh puteranya K.H. Abdul Muhaimin, yang belajar di Mekah selama kurang lebih 7 (tujuh) tahun (1928-1935), dan juga putera-putera lainnya, seperti K.H. Ahmad Shafiullah dan K.H. Ahamd Najiullah.

Adapun sebab-sebab yang menjadi dasar atau alasan berdirinya madrasah al-Djauharotunnaqiyyah di Cibeber adalah sebagai berikut:

1) Kurangnya sekolah, padahal sangat diperlukan untuk menampung anakanak yang beragama Islam dalam mempelajari ilmu keislaman.

2) Sukarnya masuk sekolah yang didirikan oleh Pemerintah Belanda. Hanya golongan tingkat atas yang bisa melanjutkan sekolah. Inipun dipilih dan diteliti oleh Pemerintah Belanda, mana yang nantinya bisa menjadi alat atau membantu mereka. Hal ini menyebabkan kebencian bangsa Indonesia dan kefanatikannya, sehingga banyak yang berfikir lebih baik menempatkan anak-anaknya di pesantren atau madrasah.

3) Tidak mampu menyekolahkan anak. Sebagai penduduk yang masih dalam jajahan Belanda, maka masyarakat susah menyekolahkan anaknya, selain alasan lainnya yaitu sekolah yang didirikan Belanda memisahkan antara agama dan pengetahuan umum.

4) Madrasah sebagai media dakwah Islam. Madrasah didirikan sebagai media dakwah Islam, merupakan penampungan dari pelajar-pelajar muslim. Karena pada waktu itu telah berdiri sekolah-sekolah Belanda yang sudah teratur administrasinya, yaitu: adanya pembayaran sekolah; ditariknya pembayaran sekolah tiap bulan; rencana pelajaran sudah teratur; dan, daftar pelajaran sudah ada.

5) Adanya tenaga pendidik yang berasal dari Cibeber atau dari luar.

6) Adanya murid/santri dari masyarakat sekitar dan yang jauh.

7) Milieu yang memungkinkan.

8) Tempat belajar yang tersedia.

Melihat uraian dari sejarah berdirinya lembaga pendidikan Islam di Banten, sudah terlihat unsur-unsur dasar dalam pendidikan Islamnya, yaitu terdapat: 
1. Azas pendidikan, mereka menjadikan al-Quran sebagai pedoman dalam menguasai dan mengajarkan Islam;

2. Tujuan pendidikan, seirama dengan tujuan penciptan manusia dalam QS. 51:56: yang artinya:

"dan aku tidak menciptakan jin dan manusia melainkan supaya mereka mengabdi kepada-Ku".

3. Materi pendidikan, bahkan secara khusus harus menamatkan materi pelajaran yang terdapat dalam kitab-kitab yang menjadi target lulus/tamat;

4. Subjek dan objek pendidikan, keikhlasan tenaga pendidik dan yang menerima pendidikan saling membutuhkan dengan tujuan bersama;

5. Metode pendidikan, sudah mempraktekkannya mulai teori sampai praktik pengabdian yang menerjunkan santri ke daerah;

6. Evaluasi pendidikan, terlihat jika mengutamakan penilaian diri yang utama dengan pengawasan yang Maha Mengawasi.

Unsur-unsur pendidikan Islam di atas, terpenuhi mulai dari sistem tradisional yaitu rumah dan masjid, sampai melembaga menjadi sebuah pondok pesantren, meskipun pada awalnya belum tertulis, tetapi secara praktis sudah diimplementasikan secara bertahap. Berarti pada saat itu, pendidikan Islam yang ada di Banten menunjukkan perkembangan dan hasil yang signifikan, dibuktikan dengan hasil pendidikannya melahirkan ulama-ulama handal dan perkembangan lembaga pendidikan Islam yang semakin tersistem.

Selanjutnya, sejarah masuknya Islam di Banten, tidak bisa dipisah dengan sejarah pendidikan Islam sampai berdirinya lembaga-lembaga pendidikan Islam, karena sultan yang memimpim Kesultanan Banten, selain sebagai penguasa juga sebagai pendakwah Islam, sebagai pendidik, sebagai imam, sebagai khatib dan berperan ganda lainnya dalam menyebarkan Islam.

\section{E. Kesimpulan}

Terdapat tiga tokoh sentral terhadap pengislaman masyarakat Banten sejak awal berdirinya Kesultanan Banten, Syarif Hidayatullah (Sunan Gunung Jati), Maulana Hasanuddin, dan Maulana Yusuf serta tujuh belas orang lainnya yang 
pernah memimpin Kesultanan Banten. Semua yang memerintah Banten, selain sebagai Sultan juga sebagai ulama, penggerak pendidikan, guru, dai dan menjadi imam shalat, peran ini mampu mengubah Banten berkultur religius islami yang sebelumnya kental dengan agama dan budaya Hindu, serta tahayul, bid'ah dan khurafat.

Ulama di Kesultanan Banten memiliki peran dan kedudukan yang sangat dihormati. Sebagai pengarah kehidupan peribadi dan masyarakat dalam beragama, memberantas kebodohan melalui pendidikan, juga sebagai penggelora semangat jihad masyarakat untuk melawan penjajah.

Ulama yang terkenal dan berhasil berjuang melalui pendidikan Islam adalah Syaikh Nawawi al-Bantani al-Jawi, terkenal dengan karya Kitab Kuning yang menjadi rujukan pesantren dalam dan luar negeri; K.H. Asnawi Caringin Banten, berhasil mendirikan Madrasah Masyarikul Anwar; K.H. Mas Abdurahman sebagai mundir Madrasah dan Pesantren Mathla'ul Anwar; Syam'un bin Alwiyah berhasil mendirikan Pondok Pesantren al-Khairiyah; K.H. Abu Shaleh dan K.H. Burhan berhasil mendirikan Pesantren dan Madrasah alDjauharotunnaqiyyah Cibeber. Lembaga pendidikan Islam ini muncul sebagai respons dari aturan Belanda yang membatasi masyarakat pribumi bersekolah di sekolah Belanda. Awalnya dilakukan secara individual di rumah masing-masing dan masjid terdekat, berkembang sampai berdirinya lembaga pendidikan Islam dalam bentuk madrasah.

\section{Daftar Pustaka}

Abdullah, Taufik. Ensiklopedi Tematis Dunia Islam: Dinamika Masa Kini. Jakarta: PT. Ichtiar Baru Van Houve, n.d.

Bellah, Robert N. Beyond Belief: Esai-Esai Tentang Agama Di Dunia Modern. Jakarta: Paramadina dan The Ford Foundation, 2000.

CIBEBER, Diposkan oleh IKBAL. "Sejarah Madrasah Al-Djauharotunnaqiyyah Cibeber." Accessed May 22, 2017. http://ikbalcibeber.blogspot.com/2011/01/sejarah-madrasah-aldjauharotunnaqiyyah.html.

Direktorat Pendidikan Diniyah dan Pondok Pesantren Departemen Agama RI. Pendidikan Islam, 2007.

Djojonegoro, Wardiman. Lima puluh tahun perkembangan pendidikan Indonesia. Departemen Pendidikan dan Kebudayaan, 1996. 
Ibrahim Anis. Al-Mu'jam Al-Wasi't. Kairo: Dar al-Maearif, 1972.

Mestoko, Sumarsono, and Indonesia Departemen Pendidikan dan Kebudayaan. Pendidikan di Indonesia dari jaman ke jaman. Departemen Pendidikan dan Kebudayaan, 1985.

Nasution, S. Sejarah pendidikan Indonesia. Jemmars, 1983.

Permana, Rahayu. 'Kyai Haji Syam'un (1883-1949): Gagasan Dan Perjuangannya.” PPs Fakultas Ilmu Pengetahuan Budaya UI, 2004.

Shihab, Alwi. Membendung Arus: Respons Gerakan Muhammadiyah terhadap Penetrasi Misi Kristen di Indonesia. Mizan, 1998.

Steenbrink, Karel A. Pesantren, madrasah, sekolah: pendidikan Islam dalam kurun moderen. Lembaga Penelitian, Pendidikan dan Penerangan Ekonomi dan Sosial, 1986.

Tjandrasasmita, Uka. Arkeologi Islam Nusantara. Kepustakaan Populer Gramedia, 2009.

Utomo, Bambang Budi, Endjat Djaenuderadjat, Kementerian Kebudayaan dan Pariwisata, Direktorat Jenderal Sejarah dan Purbakala, and Direktorat Geografi Sejarah. Atlas sejarah Indonesia: masa Islam. Jakarta]; Kharisma Ilmu: Direktorat Geografi Sejarah, Direktorat Jenderal Sejarah dan Purbakala, Kementerian Kebudayaan dan Pariwisata ;, 2012. 